Copyright (C) 2018 by Academic Publishing House Researcher

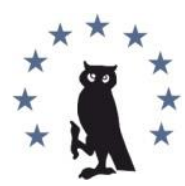

Published in the Russian Federation

European Researcher. Series A

Has been issued since 2010.

ISSN 2219-8229

E-ISSN 2224-0136

2018, 9(1): 50-57

DOI: 10.13187/er.2018.1.50

www.erjournal.ru

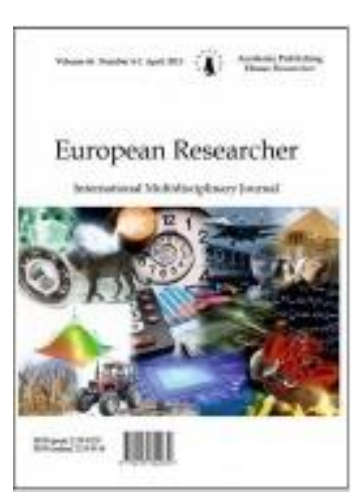

\title{
Criminal Responsibility in the Cryptosphere
}

Denis A. Pechegin a ,

a The Institute of Legislation and comparative law under the Government of the Russian Federation, Moscow, Russian Federation

\begin{abstract}
In accordance with the official forecasts of the development of the domestic economy (development Concept and security Strategy), the imbalance in world trade and capital movements will continue and may increase in the coming years, which will contribute to changes in the exchange rates of world currencies. The Russian Federation has set the goal of transforming the national currency into a leading regional reserve unit. Today, however, the full implementation of such plans is impeded by uncertainty in matters of currency and legal responsibility, including in the actively developing cryptosphere. Today, the draft Federal law "On amendments to the Federal law "On the development of small and medium-sized businesses in the Russian Federation" and the draft Federal law "On amendments to the Federal law "On digital financial assets" provide for the formation of special platforms (crypto exchange, operators, etc.), however, do not regulate the liability of professional participants of the emerging new crypto market.

Keywords: cryptocurrency, cryptosphere, responsibility, crypto currency exchange market, foreign monetary system, cryptomarket, cryptorisks, insurance, fiat money, currency.

\section{1. Введение}

Базисом финансовой системы той или иной страны являются денежные средства. На протяжении многих лет этот тезис был незыблемым для построения системы национальной финансовой безопасности. Однако общество постоянно развивается, примером чего может служить эволюция интернет-технологий и методов торговли. Вкупе с финансовым кризисом 2008-2009 годов, общим разочарованием в действующих финансовых конструкциях и нарастающим недоверием к государственным банкам возникла ситуация, при которой крупные и частные инвесторы стали искать новые способы вложения капитала и получения прибыли (Соколов, 2018).

В настоящее время и профессиональные, и непрофессиональные участники все активнее обсуждают различные моменты использования криптовалют в том или ином государстве (Поппер, 2016: 11-12). С каждым днем растет количество новостей, связанных с технологией блокчейна и виртуальными деньгами. Появляются проекты законов о регулировании в криптосфере, организуются лекционные курсы, проводятся конференции. Между тем в погоне за «новым счастьем» мы забыли об оборотной стороне медали. Нужно ясно понимать, кто именно будет нести ответственность за противоправные действия в рассматриваемой сфере?
\end{abstract}

\footnotetext{
${ }^{*}$ Corresponding author

E-mail addresses: crim5@izak.ru (D.A. Pechegin)
} 


\section{2. Материалы и методы}

Основой настоящего исследования служат правовые акты, касающиеся концепции развития Российской Федерации и Стратегии национальной безопасности Российской Федерации (Указ Президента РФ от 31.12.2015 № 683), а также проекты федеральных законов о регулировании оборота криптовалют на территории Российской Федерации, которые анализируются через призму практического преломления их положений. В статье также анализируются зарубежный опыт адаптирования системы денежного оборота к новым условиям и судебная практика. Применены формально-логический, юридикотехнический методы, метод системного анализа, сравнительно-правовой метод.

\section{3. Обсуждение}

Вопрос об ответственности в сфере валютно-денежных отношений особенно чувствителен для российской экономики. Так, важнейшие факторы обеспечения экономической безопасности страны определены в п. 58, 62 ч. IV Стратегии национальной безопасности Российской Федерации. Среди них: повышение эффективности государственного регулирования экономики в целях достижения устойчивого экономического роста; повышение производительности труда; освоение новых ресурсных источников; стабильность функционирования и развития финансовой системы, повышение ее защищенности; валютное регулирование и контроль, их оптимизация; накопление финансовых резервов; сохранение финансовой стабильности, сбалансированности бюджетной системы; совершенствование межбюджетных отношений; преодоление оттока капитала и квалифицированных специалистов; увеличение объема внутренних сбережений и их трансформация в инвестиции; снижение инфляции; обеспечение суверенитета финансовой системы, устойчивости валютного курса рубля.

Однако, постоянное увеличение количества арбитражных производств, в том числе по делам о несостоятельности (банкротстве), фактов мошенничества, а также неурегулированность статуса криптовалют, отсутствие единообразной мировой практики (Электронная валюта...: 360-369) и судебной защиты по анализируемому вопросу, нестабильность ценообразования в криптосфере, и проч. - все это суть факты, которые сегодня «формируют угрозу национальной безопасности, обозначенную в Стратегии как совокупность условий и факторов, создающих прямую или косвенную возможность нанесения ущерба объективно значимым потребностям личности, общества и государства в обеспечении их защищенности и устойчивого развития» (Электронная валюта...: 27).

Для ознакомления с судебной практикой по обозначенному вопросу можно обратиться к текстам следующих актов: Решению Ряжского районного суда г. Рязани от 26.04.2017 г. по делу № 2-160/2017; Решению Октябрьского районного суда г. Санкт-Петербурга от 16.05.2017 г. по делу № 2-1993/2017; Постановлению Шестого арбитражного апелляционного суда от 01.04.2016 № 06АП-552/2016 по делу № А73-7423/2015. По сути, данные решения обозначили тренд, согласно которому в Российской Федерации до момента должного правового урегулирования всех ключевых вопросов в криптосфере ни граждане, ни юридические лица не смогут найти защиту в лице органов государственной власти. Однако, в сознании общества еще жив пример с валютной ипотекой, когда как приговор прозвучала первая реакция на сложившуюся ситуацию - виноваты сами граждане, поскольку это был риск. И хотя Российская Федерация оказала помощь гражданам с решением данного вопроса, тем не менее, по многим причинам государство сегодня не в состоянии оказывать финансовую помощь всюду.

В таких условиях нельзя возлагать всю ответственность за совершение тех или иный действий в криптосфере на пользователя - обыкновенного гражданина, который при нынешней мировой и экономической ситуациях видит в виртуальной валюте реальную и единственную возможность заработать без использования лишних документов, договорных конструкций, без уплаты неподъемных процентов по кредитам и проч.

И хотя криптовалюта в сравнении с фиатными деньгами используется в преступных целях не столь часто (Francis, 2015), тем не менее по данным Positive Technologies (URL: https://www.kommersant.ru/doc/3566894) мошенники в 2017 году похитили 300 млн. долларов США через ICO. И речь идет не о том, что преступники выходили с проектами на 
ICO, а потом исчезали с горизонта. В подавляющем большинстве случаев злоумышленники стремятся получить контроль над самой платформой, чтобы подменить адрес криптокошелька организаторов на свой, потребовать выкуп (Сидоренко, 2016) и проч. Другим примером является разработка злоумышленниками программы майнера (Dowd, 2014: 52), которая намеренно блокирует работу других установленных на этом компьютере программ-майнеров, монополизируя, по сути, весь ресурс пользователя (т.е., тем самым нарушая право на распоряжение своим имуществом по собственному усмотрению) (Cimpanu, 2018). Пожалуй указанные преступления сегодня в большей степени следует отнести к категории mala prohibitum.

Однако в криптосфере совершаются и более «классические» (mala in se) преступления (Trautman, 2014). Так, очень распространенной в последнее время является схема, когда продавец криптовалюты встречается с покупателем в ресторане в целях обмена цифровых денег на фиатные. Покупатель показывает продавцу деньги и тот переводит ему криптовалюту. Но в этот момент появляются крепкие люди, которые заявляют, что никаких денег продавец не получит, поскольку покупатель должен сначала рассчитаться с ними. Проблема сегодня состоит в том, что завести уголовное дело по данному факту практически невозможно, ведь в законодательстве биткоин никак не отражен, а значит и ущерба никакого нет (Петров, 2017). Грабители также выслеживают тех, у кого есть криптовалюта и нападают на них в целях принудительного перевода криптовалюты на свой кошелек. Так, преступники удерживали пару из России в заложниках во время отдыха в Таиланде и под угрозой введения наркотической инъекции заставили их перевести на свой счет всю имевшуюся у них криптовалюту (URL: https://tech.onliner.by/2018/o1/18/bitcoin-55).

Так или иначе, но те участники рынка, которые выходят на ICO (получатели финансирования) стремятся привлечь денежные средства через специальные интернетсайты, интернет-площадки или криптобиржи. Представляется, что установление ответственности такой площадки (биржи) за предоставляемую участникам информацию позволит многократно снизить количество возможных мошеннических действий в указанной сфере и обеспечит ее большую стабильность на национальном уровне. Такая площадка, как минимум, должна проводить анализ деятельности юридического лица, которое намерено использовать ресурс криптобиржи для привлечения денежных средств. Такой анализ должен быть общедоступным и может содержать информацию, например, об активности деятельности юридического лица, об арбитражных и гражданских производствах с его участием, о прибыли за предыдущий год и прочее.

По нашему мнению у получателя финансирования должен быть свой отдельный счет в банке, данные о расходах с которого он предоставляет в режиме закрытого доступа (логин, пароль) участникам финансирования и соглашается с тем, что банк имеет право в любой момент заморозить средства на этом счету до выяснения обстоятельств в том случае, если средства с такого счета расходуются не в соответствии с заявленными юридическим лицом целями при привлечении денежных средств с помощью ICO, с одновременным уведомлением интернет-площадки (криптобиржи), которая размещает такую информацию на своей платформе.

Вариант: такую деятельность осуществляет сама интернет-площадка (криптобиржа). Иными словами получатель финансирования «живых денег» не получает, они все находятся на открытом в криптобирже цифровом счету. При этом сведения о расходовании денежных средств предоставляются интернет-площадкой (криптобиржей) участникам финансирования в режиме закрытого доступа (логин, пароль).

Тогда указанная система действительно сможет предоставлять участникам финансирования гарантии, что повысит привлекательность российского подхода и позволит привлечь новых инвесторов, в том числе из-за рубежа. Возможные возражения относительно предложенного подхода в известной мере понятны. Ни компании, ни криптобиржи, ни банки сегодня не желают вести свою деятельность под таким «жестким» регулированием. Однако, говоря объективно, связано это, пожалуй, не с тем, что реализация такой модели невозможна или нецелесообразна, но все же в большей степени с желанием быстро заработать «легкие» деньги. Между тем, если получатель финансирования ведет себя добросовестно и его целью является результат (честная реализация проекта), то чего ему бояться? 
Встроить новую систему в существующие правовые рамки вполне возможно, о чем свидетельствует опыт некоторых стран и, в частности, Республики Беларусь. Иностранные компании могут образовывать дочерние филиалы в Hi-Tech Park Республики Беларусь, в рамках которого уже функционируют оператор ICO (принимают заявки на ICO, проверяют соблюдение требований и выдают разрешение на краудфандинг), криптобиржа (занимается покупкой и продажей криптовалюты), а также майнеры (которые поддерживают функционирование всей системы). Сам порядок оборота криптовалюты в Hi-Tech Park Республики Беларусь выглядит следующим образом (Алейников, 2018):

1. Создание дочерней компании в Республике Беларусь;

2. Заявка на проведение ICO, направленная оператору ICO;

3. Одобрение заявки оператором ICO в Hi-Tech Park Республики Беларусь и проведение ICO (выход на рынок);

4. Краудфандинг;

5. Получение дочерней компанией криптовалюты от реализации ICO через оператора ICO;

6. Продажа криптовалюты криптобирже, которая занимается тейдинговой деятельностью (продает и покупает криптовалюту на других биржах);

7. Получение фиатных денежных средств через криптобиржу.

По заявлению В. Цюрхера в рамках организованного Внешэкономбанком Первого международного юридического форума «Криптосреда» (г. Москва, 1-2 марта 2018 г.) главная проблема криптовалюты состоит в том, что в подавляющем большинстве случаев никто не может пойти с вырученными от продажи криптовалюты по повышенному курсу (в сравнении с курсом при приобретении криптовалюты) деньгами в банк, поскольку банковская деятельность связана с законодательством о противодействии легализации (отмыванию) денежных средств (стандарты AML), а также опосредована принятыми международным сообществом правилами идентификации клиентов и истории происхождения денежных средств (стандарты КҮС и др.).

По нашему мнению выходом из этой ситуации (задаваясь также целью сохранения действующей финансовой системы и порядка денежного обращения) будет организация обмена криптовалют на фиатные деньги посредством обращения к аккредитованным государством и функционирующим при крупных банках криптобиржам, деятельность которой будет подлежать обязательному страхованию.

Представляется, что денежные средства можно будет перевести виртуальную валюту и обратно только посредством обращения к ресурсам криптобиржи (в том числе в сети Интернет). Иными словами криптобиржи будут выступать своего рода фильтром в этой новой для государств сфере, что позволит минимизировать риски при построении нового алгоритма оборота финансов, который должен обеспечить консенсус всех участников рынка.

Описанная система, на наш взгляд, позволит минимизировать случаи придания правомерного вида владению, пользованию и распоряжению денежными средствами или иным имуществом, приобретенными лицом в результате совершения им преступления, в том числе посредством совершения сделок или финансовых операций с такими денежными средствами или иным имуществом. В этом плане, вполне возможно скорректировать диспозиции статей 174 и 174.1 УК РФ, поскольку в современных условиях указанные деяния могут быть совершены не только посредством совершения сделок или финансовых операций, но также и любым другим способом. В частности, мошенники зачастую крадут криптовалюту и затем через некоторое время пытаются реализовать ее далеко за пределами территории совершения преступления (как правило, на другой бирже, предоставляющей соответствующие услуги) (Esoimeme, 2017). Другим примером может послужить опыт Швейцарии, которая намерена регулировать криптовалютные операции посредством действующего законодательства. В частности, предусматривается, что все токены будут классифицироваться на платежные, утилитарные (открывающие доступ к ресурсам специальной криптоплощадки) и токены-активы. Предполагается при этом, что утилитарные токены не должны подпадать под правила противодействия легализации (отмывания) денежных средств в силу того, что такие токены лишь предоставляют доступ к соответствующему ресурсу (URL: https://crypto.whenspeak.ru/rooms/3840/). Однако такой подход, по нашему мнению, нельзя признать удачным, поскольку утилитарные токены 
можно фактически передать другому человеку, поменять на другие токены, в том числе платежные, обменять на валюту и проч. Поэтому риск использования токенов в швейцарской юрисдикции в целях легализации (отмывания) денежных средств нельзя считать преодоленным даже несмотря на всю развитость правовых механизмов этой страны.

Примечательно, что идея создания национальной криптобиржи уже прозвучала в Китае. Ванг Пенгки (Wang Pengjie) высказал предположение, что Центральный банк Китая (the People's Bank of China) во взаимодействии с Регуляторной Комиссией Китая по безопасности (the China Securities Regulatory Comission) могут создать собственную платформу на аутентичной технологии блокчейна с особой системой верификации и национальную криптобиржу. «Мы можем предоставить компаниям легальную возможность сбора денежных средств, а индивидуальным инвесторам доступ к росту их капитала» (URL: http://bitcom.blog/member-chinas-main-political-advisory-proposes-national-crypto-tradingplatform/?i=3).

Представить криптобиржу более наглядным образом достаточно легко, если мы обратимся к официальным приложениям для современных смартфонов, позволяющих скачивать и устанавливать программы и игры на ваш телефон (AppStore и Google PlayMarket). Да, вы можете скачать на свой телефон программу из сети Интернет (особенно легко это можно сделать на телефоне с платформой Android), однако в таком случае вы не будете застрахованы от мошенников и киберпреступников, которые встраивают в «бесплатные» программы, размещенные в сети Интернет специальные скрипты, позволяющие им скачивать информацию с вашего телефона, посылать СМС-сообщения, выявлять уровень ваших банковских накоплений, красть денежные средства, подстраивать телефон под постоянную работу и скрытую добычу криптовалюты Monero и прочее (Вовнякова, 2018). Аналогичным образом сегодня при самостоятельной покупке криптовалюты никто не застрахован от фишинговых сайтов, сайтов мошенников, зеркальных сайтов официальных зарубежных бирж и т.п. Представляется, что именно аккредитованная криптобиржа позволит минимизировать риски, существующие в новой криптосфере уже сегодня.

Такой подход позволит выстроить систему, при которой в государстве наряду с «классическим» бюджетом параллельно можно будет формировать криптобюджет (либо от обложения транзакционным криптоналогом криптобирж, либо от введения налога на вывод криптовалюты в фиат). В науке, например, предлагают ввести элективный налог на анонимность с транзакции, в которой известна, по крайней мере, одна сторона (Omri, 2014). В Бразилии налог на прирост капитала в размере 15 \% подлежит уплате государству в момент продажи криптовалюты, а держатель криптовалюты на сумму более 1000 реалов должен отображать такие сведения в декларации (Облачинский, 2014).

Ведь финансовые ресурсы страны - это разные потоки (муниципальные, государственные финансы, финансы домашних хозяйств), которые не отделены друг от друга непроницаемой стеной, но взаимосвязаны (Джумов, 2007). В данном случае государство по тем или иным прогнозам сможет также переводить накопленную криптовалюту в фиат и пополнять «классический» бюджет, а уровень бюджета страны всегда будет выше 100\%. Кроме того, посредством обращения к криптобирже суды смогут обращать взыскание на криптовалюту граждан и юридических фирм и т.п.

\section{4. Результаты}

Настоящее исследование показывает, каким образом возможно интегрировать новейшие достижения в области финансов (криптовалюты и технологии, обеспечивающие их обращение) в правовую сферу валютно-денежного оборота Российской Федерации, наглядно демонстрирует возможную схему нивелирования существующих противоречий в целях обеспечения гибкости национальной валютно-денежной системы и ее устойчивости в современных реалиях.

Следует согласиться, что «при таких обстоятельствах, учитывая большое количество пользователей, вовлеченных в процесс криптообмена, вопрос о применении мер ответственности (особенно уголовной), безусловно, требует более детальной проработки. Установление тотального запрета на технологию может послужить негативным фактором 
для участников делового оборота, которые могут лишиться определенного конкурентного преимущества по сравнению со своими иностранными партнерами» (Никитин, 2017).

Вместе с тем представляется, что в условиях нестабильной экономической ситуации в стране, западных санкций, а также низкого уровня жизни в целом по стране, когда гражданин реально ограничен в способах накопления денежных средств, необходимо установить специальную (mala prohibitum) уголовную ответственность за совершение преступлений в криптосфере.

\section{5. Заключение}

Для обеспечения стабильности экономического развития страны гражданин Российской Федерации не должен опасаться, что перечисление средств интернет-площадке (и de jure, и de facto) приравнивается к их безусловной потере. «Управление рисками трудоемкий и сложный процесс, между тем, финансовой сфере особенно присущи инновации и стремительное появление новых продуктов» (Кучеров и др., 2017: 122). Для цельного регулирования криптосферы необходимо приложить все усилия для того, чтобы право выполнило по отношению к любому риску следующие функции: «легальное признание и допущение рисков, установление средств предупреждения и минимизации риска, определение меры ответственности, а также функции компенсаторных средств» (Тихомиров, Шахрай, 2012: 10).

Обозначенная в статье проблематика актуализирует ценность профессиональных компетенций на стыке специальностей, отображая будущее правовой науки (Лаптев, 2017).

Финансовая безопасность должна соответствовать реальному развитию валютноденежных отношений и быть адаптирована под современные условия, а денежно-кредитная система государства должна быть гибкой по-отношению к новым вызовам и угрозам.

\section{Литература}

Алейников, 2018 - Алейников, Д. Регулирование блокчейн-экономики: опыт Республики Беларусь, 2018 [Электронный ресурc]. URL: https://admin.whenspeak.ru/files/lkfiles/ 1006/5a981e5aab308.pdf (дата обращения: 16.03.18).

Вовнякова, 2018 - Вовнякова, А. Осторожно: Android-вирус атаковал тысячи банковских карт, 2018 [Электронный pecypc]. URL: https://hi-tech.mail.ru/news/virusobokral-tysyachy-kart/ (дата обращения: 16.03.18).

Джумов, 2007 - Джумов, А. Налоговые доходы бюджета как главный системный интегратор финансовых ресурсов. Налоги, 2007, 6: 18-20.

Кучеров и др., 2017 - Кучеров, И., Поветкина Н., Акопян, О. и др. Институты финансовой безопасности: монография, 2017, Москва.

Лаптев, 2017 - Лаптев, В. Ответственность "будущего": правовое существо и вопрос оценки доказательств. Гражданское право, 2017, 3: 32-35.

Никитин, 2017 - Никитин, К. Правовой статус криптовалют в России. ЭЖ-Юрист, 2017, 45: 6 .

Облачинский, 2014 - Облачинский, И. Биткоин: зарубежный опыт. ЭЖ-Юрист, 23: 8, 2014.

Петров, 2017 - Петров, И. Криминальный биткоин, 2017 [Электронный ресурс]. URL: https://iz.ru/684876/ivan-petrov/kriminalnyi-bitkoin (дата обращения: 16.03.18). 2016.

Поппер, 2016 - Поппер, Н. Цифровое золото: невероятная история Биткойна. Москва

Сидоренко, 2016 - Сидоренко, Э. Криминальное использование криптовалюты: международные оценки. Международное уголовное право и международная юстиция, 2016, 6: 8-10.

Соколов, 2018 - Соколов, В. Биткоин - первый глобальный инвестпроект в истории. Новая газета, 2018, 15.01.2018: 16.

Тихомиров, Шахрай, 2012 - Тихомиров, Ю., Шахрай, С. Риск и право: научное издание. Москва, 2012.

Электронная валюта... - Электронная валюта в свете современных правовых и экономических вызовов: сб. материалов Международной научн.-практ. конференции [под ред. А.С. Генкина, Э.Л. Сидоренко, О.И. Семыкина]. Москва, 2016. 
Cimpanu, 2018 - Cimpanu, C. Coinminer Comes with a Process "Kill List" to Keep Competitors at Bay, 2018 [Electronic resource]. URL: https://www.bleepingcomputer.com/news/security/ coinminer-comes-with-a-process-kill-list-to-keep-competitors-at-bay/ (Accessed: 16.03.18).

Dowd, 2014 - Dowd, K. New Private Monies: A Bit-Part Player? London, 2014.

Esoimeme, 2017 - Esoimeme, E. The Money Laundering Risks and Vulnerabilities Associated with MMM Nigeria. Journal of Money Laundering Control, 2017, Vol. 21, Issue 1: 112119.

Francis, 2015 - Francis, E. Bitcoin: Not So Scary, 2015. URL: https://ssrn.com/abstract $=2600344$.

Omri, 2014 - Omri, M.A. Conceptual Fremework for the Regulation of Cryptocurrencies. 82 University of Chicago Law Review, Dialogue, 2014, 53: 53-68.

Trautman, 2014 - Trautman, L. Virtual Currencies; Bitcoin \& What Now after Liberty Reserve, Silk Road, and Mt. Gox? Richmond Journal of Law and Technology, 2014, Vol. $20,4$.

\section{References}

Alejnikov, 2018 - Alejnikov, D. (2018). Regulirovanie blokchejn-ehkonomiki: opyt Respubliki Belarus' [Blockchain economy regulation: experience of the Republic of Belarus] [Electronic resource]. URL: https://admin.whenspeak.ru/files/lkfiles/ 1006/5a981e5aab308.pdf (Accessed: 16.03.18).

Vovnyakova, 2018 - Vovnyakova, A. (2018). Ostorozhno: Android-virus atakoval tysyachi bankovskih kart [Caution: the Android virus has attacked thousands of bank cards]. [Electronic resource]. URL: https://hi-tech.mail.ru/news/virus-obokral-tysyachy-kart/ (Accessed: 16.03.18).

Dzhumov, 2007 - Dzhumov, A. (2007). Nalogovye dohody byudzheta kak glavnyj sistemnyj integrator finansovyh resursov [Tax revenues of the budget as the main system integrator of financial resources]. Nalogi, 6: 18-20.

Kucherov i dr., 2017 - Kucherov I., Povetkina N., Akopyan O etc. (2017). Instituty finansovoj bezopasnosti [Financial security institutes]: monografiya. Moscow.

Laptev, 2017 - Laptev V. (2017). Otvetstvennost' "budushchego" [The responsibility of the" future"]: the legal substance and the question of the evaluation of evidence]: pravovoe sushchestvo i vopros ocenki dokazatel'stv. Grazhdanskoe pravo, 3: 32-35.

Nikitin, 2017 - Nikitin, K. (2017). Pravovoj status kriptovalyut v Rossii [The legal status of cryptocurrencies in Russia]. EHZH-Yurist, 45: 6.

Oblachinskij, 2014 - Oblachinskij, I. (2014). Bitkoin: zarubezhnyj opyt [Bitcoin: foreign experience]. EHZH-Yurist, 23: 8.

Petrov, 2017 - Petrov, I. (2017). Kriminal'nyj bitkoin [Criminal bitcoin]. [Electronic resource]. URL: https://iz.ru/684876/ivan-petrov/kriminalnyi-bitkoin (Accessed: 16.03.18).

Popper, 2016 - Popper, N. (2016). Cifrovoe zoloto: neveroyatnaya istoriya Bitkojna [Digital gold: the incredible story of Bitcoin], Moscow.

Sidorenko, 2016 - Sidorenko, E. (2016). Kriminal'noe ispol'zovanie kriptovalyuty: mezhdunarodnye otsenki [Criminal use of cryptocurrency: international assessments]. Mezhdunarodnoe ugolovnoe pravo i mezhdunarodnaya yusticiya, 2016, 6: 8-10.

Sokolov, 2018 - Sokolov, V. (2018). Bitcoin - pervyj global'nyj investproekt v istorii [Bitcoin is the first global investment project in history]. Novaya gazeta, 15.01.2018: 16.

Tihomirov, Shahraj, 2012 - Tihomirov, Yu., Shahraj, S. (2012). Risk i pravo [Risk and right]: nauchnoe izdanie. Moscow.

Ehlektronnaya valyuta... - Ehlektronnaya valyuta v svete sovremennyh pravovyh i ehkonomicheskih vyzovov [Electronic currency in the light of modern legal and economic challenges]: sb. materialov Mezhdunarodnoj nauchn.-prakt. konferencii (2016). [pod red. A.S. Genkina, E.L. Sidorenko, O.I. Semykina], Moscow.

Cimpanu, 2018 - Cimpanu, C. (2018). Coinminer Comes with a Process "Kill List" to Keep Competitors at Bay [Electronic resource]. URL: https://www.bleepingcomputer.com/news/ security/coinminer-comes-with-a-process-kill-list-to-keep-competitors-at-bay/ (Accessed: 16.03.18).

Dowd, 2014 - Dowd, K. (2014). New Private Monies: A Bit-Part Player? London.

Esoimeme, 2017 - Esoimeme, E. (2017). The Money Laundering Risks and Vulnerabilities Associated with MMM Nigeria. Journal of Money Laundering Control, Vol. 21, Issue 1: 112-119. 
Francis, 2015 - Francis, E. (2015). Bitcoin: Not So Scary [Electronic resource]. URL: https://ssrn.com/abstract=2600344 (Accessed: 16.03.18).

Omri, 2014 - Omri, M. (2014). A Conceptual Fremework for the Regulation of Cryptocurrencies. 82 University of Chicago Law Review, Dialogue 53: 53-68.

Trautman, 2014 - Trautman, L. (2014). Virtual Currencies; Bitcoin \& What Now after Liberty Reserve, Silk Road, and Mt. Gox? Richmond Journal of Law and Technology, 2014, Vol. 20, 4 .

\section{Уголовная ответственность в криптосфере}

Денис Андреевич Печегин а , *

а Институт законодательства и сравнительного правоведения при Правительстве Российской Федерации, г. Москва, Российская Федерация

Аннотация. В соответствии с официальными прогнозами развития отечественной экономики (Концепции развития и Стратегии безопасности) в ближайшие годы сохранится и, возможно, усилится дисбаланс в области мировой торговли, движении капиталов, что будет способствовать изменению курсов мировых валют. Перед Российской Федерацией поставлена цель преобразования отечественной валюты в ведущую региональную резервную единицу. Однако сегодня полноценной реализации таких планов препятствует неопределенность в вопросах валютно-правовой ответственности, в том числе в активно развивающейся криптосфере. Сегодня и проект федерального закона «О внесении изменений в Федеральный закон «О развитии малого и среднего предпринимательства в Российской Федерации», и проект федерального закона «О внесении изменений в Федеральный закон «О цифровых финансовых активах», предусматривают образование специальных площадок (криптобирж, операторов и проч.), однако не регулируют вопросы ответственности профессиональных участников формирующегося нового крипторынка.

Ключевые слова: криптовалюта, криптосфера, ответственность, криптобиржа, валютно-денежная система, крипторынок, крипториски, страхование, фиатные деньги, валюта.

* Корреспондирующий автор

Адреса электронной почты: crim5@izak.ru (Д.А. Печегин) 